\title{
DAMPAK PERAN PENDAMPING TERHADAP PENGEMBANGAN USAHA DARI KUBE (KELOMPOK USAHA BERSAMA) DI KOTA AMBON
}

\author{
Badhmore Nanlohy ${ }^{1}$, Nandang Mulyana ${ }^{2}$, Rudi Saprudin Darwis ${ }^{3}$ \\ ${ }^{1}$ Mahasiswa Pascasarjana Kesejahteraan Sosial Universitas Padjadjaran \\ Email: badhmore17001@mail.unpad.ac.id \\ ${ }^{2}$ Departemen Kesejahteraan Sosial Universitas Padjadjaran \\ Email: mulyananandang@yahoo.com \\ ${ }^{3}$ Departemen Kesejahteraan Sosial Universitas Padjadjaran \\ Email:rudi.darwis@unpad.ac.id
}

\begin{abstract}
Abstrak
Penelitian ini bertujuan untuk mengidentifikasi dan mendeskripsikan dampak dan manfaat peran pendamping terhadap pengembangan usaha dari kelompok usaha bersama (KUBE). Peran pendamping KUBE akan dianalisis dengan menggunakan empat peran dan keterampilan yang disampaikan oleh Jim Ife dan Frank Tesoreiro (2006) yaitu peran fasilitatif, peran educational, peran representasional, dan peran teknis. Jenis penelitian yang penulis gunakan dalam penulisan ini adalah penelitian kualitatif dengan teknik pengumpulan data yaitu: observasi (pengamatan), wawancara mendalam dan studi dokumentasi yang berkaitan dengan masalah penelitian. Hasil penelitian menemukan bahwa melalui peran fasilitatif kelompok akan memiliki semangat untuk menjalankan usaha, kelompok difasilitasi melalui berbagai ide dan gagasan dalam menjalankan usaha, dan adanya pendekatan personal pada masing-masing anggota kelompok ketika terdapat masalah di dalam kelompok. Dalam peran mendidik, pendamping akan meningkatkan kesadaran seluruh anggota kelompok terhadap pentingnya usaha yang mereka jalankan dan memberikan informasi yang penting bagi perkembangan usaha mereka. Yang ketiga dalam peran representasi pendamping akan membantu kelompok dalam menggunakan media yang tepat dalam mengembangkan usaha, membangun jaringan kerja dengan pihak lain, dan saling berbagai pengetahuan dan pengalaman. Dan terakhir, peran dan keterampilan teknis, pendamping membantu kelompok untuk menggunakan komputer, dan melakukan presentasi verbal maupun tertulis, dalam menjalankan dan mengembangkan usaha mereka.
\end{abstract}

Kata kunci: KUBE, Peran Pendamping KUBE, Dinas Sosial Kota Ambon.

\section{IMPACT OF COORDINATING ROLE TOWARDS BUSINESS DEVELOPMENT FROM KUBE (JOINT BUSINESS GROUP) IN AMBON CITY}

\begin{abstract}
This study aims to identify and describe the impact and benefits of the role of counterparts on the business development of the joint venture group (KUBE). The role of KUBE companions will be analyzed using four roles and skills delivered by Jim Ife and Frank Tesoreiro (2006), namely facilitative roles, educational roles, representational roles, and technical roles. This type of research that the author uses in this study is qualitative research with data collection techniques, namely: observation (observation), in-depth interviews and documentation studies relating to research problems. The results of the study found that through the facilitative role the group will have a passion for running a business, the group is facilitated through various ideas and ideas in running a business, and there is a personal approach to each group member when there are problems in the group. In the role of educating, the facilitator will increase the awareness of all
\end{abstract}


group members of the importance of the business they run and provide information that is important for the development of their business. The third in the role of companion representation will help the group in using the right media in developing businesses, building networks with other parties, and sharing a variety of knowledge and experiences. And finally, technical roles and skills, the facilitator helps the group to use computers, and makes verbal and written presentations, in running and developing their business.

Keywords: KUBE, Role of KUBE Companion, Ambon City Social Service

\section{PENDAHULUAN}

Masalah kemiskinan merupakan masalah kompleks yang dipengaruhi oleh berbagai faktor yang saling berkaitan antara lain tingkat pendapatan, kesehatan, pendidikan, akses terhadap barang dan jasa, lokasi geografis, gender dan kondisi lingkungan. Karena sifatnya yang begitu kompleks maka perlu adanya pengkajian yang mendalam terhadap masalah ini.

United Nations Development Program (UNDP, 2010) dalam laporannya mengatakan bahwa kemiskinan tidak dapat dipahami semata sebagai kemelaratan atau ketimpangan dalam distribusi asset material, immaterial dan sumber daya tetapi juga tentang pengucilan sosial, budaya marginalisasi, dan proses prospek dan peluang yang dirampas. Hal ini menjadikan kemiskinan tidak hanya menjadi masalah bagi negara berkembang, negara maju sekalipun tidak bisa menghilangkan kemiskinan dari masyarakatnya.

Provinsi Maluku menempati wilayah seluas $712.480 \mathrm{~km}$ dengan sekitar 92,4 persen diantaranya adalah lautan dan hanya 7,6 persen saja yang berupa daratan. Selain sebagai provinsi kepulauan dengan potensi kelautan yang besar, Maluku sejak dahulu terkenal sebagai pulau penghasil rempah-rempah yang kaya. Pada tahun 2017 Provinsi Maluku terdiri atas sembilan kabupaten dan dua Kota dengan jumlah penduduk sekitar 1.744,7 ribu jiwa.

Walaupun dilimpahi dengan potensi sumber daya alam, kemiskinan di Maluku masih tercatat sebagai salah satu yang tertinggi di Indonesia. Pada tahun 2017, Maluku menempati urutan provinsi ke 4 provinsi termiskin di Indonesia dengan jumlah angka kemiskinan sebesar 119.825 per kepala keluarga berdasarkan data Tim Nasional Pemercepat Pengetasan Kemiskinan (TNP2K). Salah satu Kabupaten/Kota yang ada di Provinsi Maluku adalah Kota Ambon, sebagai Ibu Kota Provinsi, Kota Ambon sendiri menempati urutan terakhir dari 11 Kabupaten/Kota dalam tingkat kemiskinan yang ada di provinsi Maluku. Jumlah keluarga miskin yang ada di Kota Ambon sebanyak 11.265 kepala keluarga atau sebesar 4,42 persen dari jumlah 395.423 kepala keluarga di Kota Ambon (Dinas Sosial Kota Ambon dan Dinas Sosial Provinsi Maluku, 2015).

Penanggulangan kemiskinan telah dilakukan oleh berbagai lembaga pemerintah saat ini, baik lembaga 
pemerintah yang ada dipusat maupun yang ada di daerah-daerah pada berbagai Provinsi, Kabupaten/Kota. Kementerian Sosial adalah salah satu lembaga negara yang menangani masalah kemiskinan. Salah satu bentuk program pengentasan kemiskinan dari Kementerian Sosial R.I adalah Program Pemberdayaan Fakir Miskin (P2FM) dengan pendekatan Kelompok Usaha Bersama (KUBE). Program KUBE yang berasal dari Kementerian Sosial dalam pelaksanaannya diberikan tanggung jawab kepada Dinas Sosial pada setiap Kabupaten/Kota pada masing-masing provinsi di Indonesia.

Untuk Kota Ambon Program KUBE dioperasikan melalui Dinas Sosial Kota Ambon. Pada tahun 2015 terdapat 52 Kelompok yang diberikan bantuan Program KUBE untuk menjalankan usaha mereka. Berdasarkan hasil evaluasi dari Dinas Sosial Kota Ambon pada akhir 2015 dan awal tahun 2016, dari 52 kelompok yang diberikan bantuan terdapat 32 kelompok yang masih aktif dalam menjalankan usaha dan 20 kelompok lainnya mengalami kegagalan dalam menjalankan usaha mereka. Berdasarkan data tersebut di atas dapat dijelaskan bahwa hampir setengah dari bantuan KUBE yang diberikan mengalami kegagalan dalan perjalanannya. Mujiadi (2013) menjelaskan bahwa, beberapa penyebab kegagalan KUBE dikarena implementasi kebijakan penanggulangan kemiskinan di lapangan belum sepenuhnya mengikuti panduan yang ada. Hal tersebut terjadi sejak tahap pembentukan KUBE, proses operasional, pendampingan hingga tahap pengembangan KUBE. Selanjutnya Anwar Sitepu (2016) juga mengungkapkan beberapa penyebab kegagalan KUBE antara lain bantuan yang diberikan kurang sesuai dengan potensi masyarakat penerima bantuan, bantuan diberikan dengan terburu-buru demi menjawab terlaksannya program KUBE, dan pendamping KUBE yang kurang handal.

Selain faktor-faktor penyebab kegagalan KUBE yang disampaikan di atas ternyata ditemukan juga faktor penyebab keberhasilan KUBE antara lain: Hendrik Yasin (2015) menemukan bahwa faktor penyebab keberhasilan KUBE yaitu: masyarakat mampu menopang usaha yang dijalankan oleh kelompok, kelompok menjalankan usaha yang dijalankan diperlukan oleh masyarakat, pendamping membantu memfasilitasi sumber bantuan yang dapat dimanfaatkan oleh kelompok, terciptanya kerja sama yang baik antara kelompok dan pendamping dapat mengatasi masalah internal kelompok. Samsul Alil Bahril (2017) juga menemukan bahwa keberhasilan KUBE pengaruhi oleh kerjasama yang terjalin baik antara pengelola, anggota, pemasok bahan baku, pemerintah, pasar dan pihak lainnya yang terkait, adanya motivasi untuk mengikuti kegiatan di KUBE, sifat transparan dan saling menjaga kepercayaan dari semua pihak, pendamping berperan penting dalam menghubungankan pihak-pihak yang dapat membantu usaha kelompok. 
Dari beberapa faktor penyebab keberhasilan dan kegagalan KUBE yang disampaikan di atas, ditemukan bahwa pendamping mempunyai peran yang cukup signifikan dalam mempengaruhi kelangsungan maupun perkembangan KUBE dilapangan.

Menurut Banks (2003) pada beberapa program sosial di negaranegara maju keberadaan pendamping dapat membantu meningkatkan efektivitas program melalui pemberian informasi serta pemberdayaan kepada pihak penerima bantuan. Selanjutnya dalam penelitian Putri dan Pambudi (2014) mengenai Efektivitas Pelaksanaan Program Kelompok Usaha Bersama (Kube) Di Kelurahan Tegalpanggung, Kecamatan Danurejan, Kota Yogyakarta menyarankan agar perlu adanya pendampingan yang lebih intens sehingga mengurangi kemacetan usaha dan dapat lebih membantu kelompok dalam mengelola usaha. Pentingnya pendampingan juga disampaikan oleh Subing (2013) bahwa pendampingan, mempunyai peran sangat penting bagi keberhasilan dan berkembangnya Kelompok Usaha Bersama.

Sejak pertama kali dilaksanakan pada Tahun 2012, pada awalnya program KUBE berjalan tanpa diberi pendampingan, karena Dinas Sosial Kota Ambon menganggap bahwa masyarakat mampu mengelola dan mengembangkan usaha mereka dengan bantuan KUBE secara mandiri, selain itu keterbatasan anggaran juga menjadi alasan bagi pihak Dinas Sosial Kota
Ambon untuk melakukan perekrutan dan membiayai tenaga pendamping.

Setelah 2 tahun berjalan tanpa diberi pendampingan pihak Dinas Sosial Kota Ambon kemudian menyadari bahwa banyak dana APBD yang telah dikeluarkan untuk membiayai program KUBE, namun hasilnya belum memberi dampak yang signifikan untuk membantu masyarakat penerima bantuan dalam memenuhi kebutuhan hidup mereka. Hal ini dikarenakan banyak kelompok penerima bantuan KUBE mengalami kegagalan dalam menjalankan usaha mereka. Sehingga pada tahun 2015 melalui pertemuan bersama dengan Dinas Sosial Provinsi dan Pemerintah Kota Ambon mereka menyampaikan permasalah yang mereka hadapi dan meminta solusi atas permasalahan tersebut.

Menindaklanjuti pertemuan tersebut Dinas Sosial Provinsi Maluku mengerahkan tenaga pendamping program yang mereka miliki untuk membantu Dinas Sosial Kota Ambon dalam melalukan pengontrolan terhadap kelompok-kelompok KUBE.

Pendampingan terhadap kelompok penerima bantuan KUBE dimulai sejak tahun 2015 jumlah tenaga pendamping KUBE berjumlah 25 orang yang terdiri dari 24 anggota pendamping dan 1 kordinator wilayah Kota Ambon. Saat itu pendamping KUBE mendampingi kurang lebih 54 Kelompok penerima bantuan KUBE dengan rasio 1 pendamping mendampingi 2 kelompok KUBE.

Seiring berjalannya waktu para pendamping KUBE yang tadinya 
bertugas mendampingi KUBE pada Kota Ambon mulai diarahkan untuk mendampingi KUBE-KUBE pada 4 Kabupaten lain pada wilayah Provinsi Maluku. Hal ini membuat jumlah tenaga pendamping KUBE pada wilayah Kota Ambon menjadi berkurang saat ini hanya tersisa 7 orang pendamping yang terdiri dari 1 kordinator untuk wilayah Kota Ambon, dan 6 orang anggota pendamping.

Saat ini 7 orang pendamping tersebut mendampingi $34 \mathrm{KUBE}$ yang tersebar pada berbagai wilayah yang termasuk dalam lingkup daerah Kota Ambon dengan rasio 1 orang pendamping mendampingi 4-5 kelompok. Berdasarkan hasil wawancara penulis menemukan bahwa terkadang pendamping mengalami kesulitan dalam mendampingi 4-5 kelompok, salah satu kesulitannya adalah dalam membagi waktu untuk mendampingi kelompok-kelompok tersebut.

Menurut Jim Ife dan Frank Tesoreiro (2006) seorang pendamping memiliki 4 jenis peran yaitu Facilitative roles (peranan fasilitatif) yaitu peran untuk membangkitkan semangat atau memberi dorongan kepada individuindividu, kelompok-kelompok dan masyarakat untuk menggunakan potensi dan sumber yang dimiliki untuk meningkatkan produktivitas dan pengelolaan usaha secara efisien. Yang kedua Educational roles (peranan educational), yaitu peran dalam memberikan masukan dalam rangka peningkatan pengetahuan, keterampilan serta pengalaman bagi individu-individu, kelompok-kelompok dan masyarakat. Yang ketiga Representational roles (peranan representasional), yaitu peran dalam melakukan interaksi dengan pihak luar bagi kepentingan masyarakat dan memberi manfaat bagi masyarakat. Dan yang terakhir Technical roles (peranan teknis), peran ini berkaitan dengan halhal teknis dalam membantu proses pengambangan masyarakat.

$$
\text { Melihatnya pentingnya }
$$

pendampingan dalam suatu program yang diarahkan kepada masyarakat maka dalam pelaksanaan program KUBE mekanisme pendampingan merupakan salah satu strategi dalam menentukan keberhasilan program pemberdayaan bagi masyarakat itu sendiri. Pendamping KUBE diharapkan hadir sebagai agen perubah yang terlibat untuk membantu dalam rangka mengoptimalkan kelompok ketika menjalankan usaha mereka. Berkaitan dengan pelaksanaan KUBE di Kota Ambon maka dalam penelitian ini peneliti ingin melihat bagaimana dampak dari peran yang dilakukan oleh pendamping KUBE di Kota Ambon sebagaimana disampaikan oleh Jim Ife dan Frank Tesoreiro.

\section{METODE}

Metode yang digunakan dalam penelitian ini adalah metode penelitian deskriptif kualitatif karena peneliti ingin menggambarkan fakta-fakta atau keadaan ataupun gejala yang tampak dalam pendampingan terhadap 
kelompok usaha bersama pada Dinas Sosial Kota Ambon. Metode kualitatif, adalah suatu proses penelitian dan pemahaman yang berdasarkan pada metodologi yang menyelidiki suatu fenomena sosial dan masalah manusia. Pada pendekatan ini, peneliti membuat suatu gambaran kompleks, meneliti kata-kata, laporan terinci dari pandangan informan, dan melakukan studi pada situasi yang alami (Creswell, dalam Iskandar, 2009). Penentuan informan pada penelitian ini dilakukan dengan teknik purposive sampling, dimana pemilihan dilakukan secara sengaja berdasarkan kriteria yang telah ditentukan dan ditetapkan berdasarkan tujuan penelitian. Adapun kriteria dan informan yang ditunjuk atau dipilih dalam penelitian ini terdiri dari:

1. Pegawai Dinas Sosial Kota Ambon yang menangani program KUBE yang terdiri dari: sub bagian perencanaan, monitoring dan evaluasi, bidang bina swadaya sosial, seksi penyuluhan dan bimbingan sosial, dan unit pelaksana teknis dinas.

2. Pendamping program KUBE.

3. Kelompok KUBE

Teknik pengumpulan data yang digunakan dalam penelitian ini, terdiri dari: pengamatan (observasi), wawancara mendalam (indepth interview) dan studi pustaka. Teknik analisis data yang dipakai dalam penulisan ini dilakukan secara kualitatif, melalui proses mencari dan menyusun data yang diperoleh secara sitematis dan membuat kesimpulan berdasarkan data yang telah dianalisis. Menurut Miles dan Huberman (dalam Sutopo dan Arief, 2010) terdapat tiga teknik analisisi data kualitatif yaitu reduksi data, penyajian data dan penarikan kesimpulan. Lokasi penelitian yaitu pada Dinas Sosial Kota Ambon sebagai lembaga pemerintah yang melakukan berbagai fungsi dan tanggung jawab dalam kaitannya dengan berbagai penanganan masalah kemiskinan termasuk program KUBE yang di dalamnya terdapat pendamping KUBE yang merupakan mitra Dinas Sosial sendiri dan juga meliputi kelompok usaha bersama yang diberdayakan dengan bantuan KUBE.

\section{HASIL DAN PEMBAHASAN}

Peran pendamping KUBE dianalisis berdasarkan empat peran dan keterampilan yang disampaikan oleh Jim Ife dan Frank Tesoreiro (2006) yaitu, peran dan keterampilan fasilitatif, peran dan keterampilan mendidik, peran dan keterampilan representasi, dan peran dan keterampilan teknis. Adapun beberapa peran penting dari pendamping KUBE yang mampu mempengaruhi perkembangan usaha dari kelompok penerima bantuan KUBE antara lain:

A. Peran dan Keterampilan Fasilitatif merupakan peran yang berkaitan dengan bagaimana pendamping menstimulasi dan menunjang pengembangan kelompok yang menerima bantuan KUBE dalam peran ini terdapat 3 peran spesifik pendamping yang dapat membantu 
KUBE dalam melakukan pengembangan usaha yaitu:

1. Peran dalam memberikan semangat sosial

Yang dimaksudkan oleh Jim Ife dan Frank Tesoreiro (2006) mengenai peran dalam pemberian semangat sosial adalah mengenai bagaimana seorang pendamping membuat mereka yang didampingi turut terlibat dalam aktifitas bersama. Pendamping dalam hal ini mempunyai kemampuan menginspirasi, menstimulasi, menggerakan dan memotivasi orang lain untuk terlibat dalam kegiatan bersama.

Berkaitan dengan apa yang disampikan oleh Jim Ife dan Frank Tesoreiro (2006) mengenai peran dalam pemberian semangat sosial maka pendamping KUBE sebagaimana ditemukan dilapangan melakukan perannya untuk menggerakan dan memotivasi kelompok untuk ada dalam sebuah kegiatan menjalankan usaha mereka secara bersama-sama. Pemberian semangat ini terus pendamping lakukan selama pendamping berada bersama-sama dengan kelompok. Dengan harapan kelompok akan selalu memiliki semangat dan rasa kebersamaan dalam menjalankan usaha mereka.

Pentingnya semangat untuk menjalankan usaha ini perlu juga diimbagi dengan komitmen yang kuat dari setiap anggota sehingga usaha mereka dapat terus dijalankan dan memungkinkan untuk adanya pengembangan usaha.
Menurut pendamping semangat sangat dibutuhkan dalam segala aktivitas kerja tanpa semangat, maka kesuksesan tidak akan diraih. Peran pendamping KUBE disini akan membantu anggota kelompok tersebut untuk meningkatkan kembali semangat kerjanya. Ketika timbul semangat untuk bekerja di dalam diri anggota tersebut, dia akan melibatkan dirinya untuk bekerja sama dengan anggota kelompok yang lain dalam menjalankan usaha mereka.

Dengan semangat sosial yang tinggi maka, pekerjaan yang di kerjakan oleh kelompok akan lebih cepat diselesaikan dan berhasil dengan baik. Hal ini tentu saja akan membantu kelompok untuk mengerjakan pekerjaan yang lain dan akan membantu kelompok untuk melakukan peningkatan usaha mereka.

2. Peran dalam memfasilitasi kelompok

Menurut Jim Ife dan Frank Tesoreiro (2006) Pendamping menghabiskan sebagian besar waktunya bersama kelompok untuk memfasilitasi kelompok. Pendamping membantu kelompok untuk mencapai hasil yang terbaik dalam membuat keputusan bagi kepentingan bersama, selain itu pendamping memfasilitasi kelompok untuk mengembangkan sumber daya yang tersedia baik yang ada pada kelompok maupun yang berada di luar kelompok yang berpotensi positif bagi kelompok.

Sehubungan dengan apa yang disampaikan oleh Jim Ife dan Frank 
Tesoreiro di atas maka pendamping KUBE juga turut menopang kelompok dalam menjalankan usaha baik melalui sumbangan pemikiran berupa ide dan gagasan-gagasan baru dalam menjalankan usaha maupun dalam memecahkan masalah-masalah dalam kelompok ketika kelompok mengalami kendala-kendala dalam menjalankan usaha mereka. Pendamping juga memfasilitasi kelompok dalam pertemuan-pertemuan bersama dengan pihak Dinas Sosial Kota Ambon ketika mereka melakukan monitoring dan evaluasi bagi kelompok.

Peran ini merupakan peran yang terlihat cukup dapat membantu kelompok dalam melakukan pengembangan usaha. Dalam peran ini pendamping tidak hanya terlibat untuk memfasilitasi kelompok dalam bentuk pemberian semangat, motivasi, pengetahuan dan pengalamanpengalaman yang ia miliki. Dalam peran ini pendamping juga turut terlibat memfasilitasi kelompok untuk memperoleh konsumen (masyarakat) yang mau untuk menggunakan jasa atau produk dari kelompok mereka.

Dalam peran ini pendamping bersama dengan kelompok juga akan mencoba mencari kreatifitas baru yang dapat dikembangkan baik dari segi jasa maupun produk yang digunakan untuk mendapatkan minat konsumen, dengan demikian maka kelompok memperoleh konsumen yang tetap mau menggunakan jasa atau produk yang mereka berikan.
3. Peran dalam melakukan komunikasi pribadi.

Menurut Jim Ife dan Frank Tesoreiro (2006) sangatlah penting bagi seorang pendamping untuk mempunyai komunikasi yang baik hal ini dikarenakan dalam kesehariannya ia akan membangun komunikasi dengan masyarakat, kelompok, maupun individu yang tentu saja memiliki latar belakang yang berbeda dengannya.

Ketika melaksanakan peran ini di dalam kelompok seorang pendamping KUBE akan lebih banyak untuk mendengar apa yang disampaikan oleh anggota kelompok, pendamping akan mendengarkan dengan apa hati-hati apa yang disampaikan, kemudian memahami maksud dari apa yang disampaikan sebelumnya nanti ia berbicara.

Dalam melakukan komunikasi pendamping akan berhati-hati dengan cara bicara dan bahasa yang ia gunakan sehingga lawan komunikasinya tidak ada yang merasa tersinggung dengan apa yang disampaikannya

Komunikasi menjadi salah satu faktor penting dalam menunjang keberhasilan usaha bagi kelompok, karena selain menjalankan perannya dalam membangun komunikasi personal di dalam kelompok, pendamping juga akan membantu kelompok dalam membangun komunikasi yang baik, ketika kelompok akan memasarkan jasa atau produk yang dimiliki.

Dalam hubungannya dengan pengembangan usaha, maka peran 
pendamping dalam melakukan komunikasi pribadi adalah dengan tujuan membangun kerjasama antar kelompok dengan pihak-pihak yang dapat membantunya dalam memasarkan hasil produk maupun mau menggunakan jasa dari kelompokkelompok tersebut.

B. Peran dan Keterampilan Mendidik merupakan peran pendamping dalam memberikan pengetahuan, keterampilan, maupun pengalamannya bagi kelompok KUBE yang didampingi. Dalam peran ini terdapat 2 peran spesifik pendamping yang dapat membantu KUBE dalam melakukan pengembangan usaha yaitu:

1. Peran dalam melakukan peningkatan kesadaran

Menurut Jim Ife dan Frank Tesoreiro (2006) pendamping melakukan peran peningkatan kesadaran untuk membantu individu, kelompok maupun masyarakat agar mampu untuk mandiri dengan kemampuan yang mereka miliki.

$$
\text { Dalam }
$$

pelaksanaannya

pendamping KUBE akan memberikan pemahaman bagi setiap anggota kelompok agar memiliki rasa kebersamaan dalam menjalankan usaha mereka secara bersama, sehingga mereka mampu mandiri dengan usaha yang mereka jalankan. Pendamping juga turut membantu kelompok dalam menganalisis berbagai kelebihan dan kekurangan yang ada pada setiap anggota kelompok hal ini bukan dimaksudkan untuk mencari tahu siapa anggota kelompok yang terbaik namun, hal ini perlu dilakukan agar setiap anggota kelompok mampu mengisi berbagai kekurangan yang ada pada mereka satu dengan yang lain.

Peran pendamping disini adalah meningkatkan kesadaran pada setiap anggota kelompok agar mereka dapat memberikan kontribusi nyata dalam menjalankan usaha secara bersama, setiap anggota kelompok diharapkan dapat memiliki kesadaran untuk bekerja secara maksimal sesuai dengan tugas yang telah diberikan.

Selain menganalisis pada anggota kelompok, pendamping juga dapat memberikan masukan kepada kelompok mengenai kelebihan maupun kekurangan dari usaha yang mereka sedang jalankan agar kelompok mampu melakukan evaluasi untuk melihat faktor-faktor apa saja yang menguntungkan dan yang merugikan jika mereka menjalankan usaha tersebut. Dengan mengetahui kekurangan dan kelebihan yang ada kelompok akan dapat memprediksi tindakan selanjutnya yang akan diambil baik dalam menjalankan usaha maupun mengembangkan usaha tersebut.

2. Peran dalam memberikan informasi

Peran dalam memberikan informasi sebagaimana yang disampaikan oleh Jim Ife dan Frank Tesoreiro (2006) yaitu mengenai bagaimana pendamping memberikan informasi yang relevan yang dapat membantu masyarakat merencanakan cara yang paling baik untuk memenuhi kebutuhan mereka dan melibatkan 
sebanyak mungkin orang untuk terlibat dalam kegiatan pengembangan masyarakat.

Dalam menjalankan peran ini pendamping KUBE akan membantu kelompok untuk memberikan informasi yang relevan dengan usaha yang sedang dijalankan oleh mereka sehingga dapat membantu mereka merencanakan cara yang paling baik dalam memaksimalkan usaha yang sedang mereka jalankan. Peran pemberian informasi diadakan untuk membekali anggota kelompok dengan pengetahuan tentang data dan fakta mengenai jenis usaha yang mereka jalankan sehingga mereka kemudian akan lebih mampu untuk mengatur dan merencanakan usaha mereka sendiri menjadi lebih baik dari waktu ke waktu.

Dengan adanya informasi yang baik maka kelompok usaha dapat mengetahui apa yang dibutuhkan oleh konsumen sehingga mereka dapat meningkatkan produktivitas, mengurangi stok material produksi, menghilangkan kegiatan yang tidak memiliki manfaat (nilai tambah), serta meningkatkan layanan dan kepuasan pelanggan.

C. Peran dan Keterampilan Representasi merupakan peran dalam melakukan interaksi dengan masyarakat bagi kepentingan kelompok KUBE dan memberikan manfaat bagi kelompok KUBE. Dalam peran ini terdapat 3 peran spesifik pendamping yang dapat membantu KUBE dalam melakukan pengembangan usaha yaitu:

\section{Peran dalam menggunakan media}

Peran pendamping KUBE dalam menggunakan media dilakukan untuk menyebarkan informasi mengenai jenisjenis usaha yang dijalankan oleh KUBE saat ini. Menurut Jim Ife dan Frank Tesoreiro (2006) Media yang dapat digunakan oleh seorang pendamping bagi pengembangan masyarakat dapat berupa berbagai pernyataan pers, melakukan wawancara pada media eletronik (TV dan radio) dan media cetak, maupun berpartisipasi dalam sebuah perdebatan atau forum-forum diskusi.

Kecenderungan masyarakat di Kota Ambon yang sering menggunakan media sosial, dimanfaatkan oleh pendamping KUBE untuk mengarahkan kelompok mencari tahu lebih banyak mengenai apa yang dibutuhkan oleh masyarakat dan bagaimana kelompok dapat menggunakan usaha mereka tersebut untuk memenuhi kebutuhan masyarakat, dengan demikian maka usaha kelompok dapat terus berjalan.

Penggunaan media yang dilakukan oleh pendamping KUBE adalah untuk menyebarkan informasi mengenai jenisjenis usaha yang dimiliki oleh masingmasing KUBE, dengan tujuan agar diketahui oleh masyarakat luas dan dapat menambah jumlah konsumen yang menggunakan jasa atau produk yang dimiliki oleh KUBE.

Dengan bertambahnya konsumen maka kelompok pun harus dapat bekerja untuk memenuhi kebutuhan para konsumen tersebut. Hal ini merupakan 
peluang sekaligus tantangan bagi kelompok, sebab jika mereka mampu untuk menjawab kebutuhan konsumen, maka mereka akan memperoleh pendampatan dan usaha mereka akan terus berjalan dan bisa saja mereka akan mampu untuk mengembangkan usaha mereka.

2. Peran dalam membangun jaringan kerja

Menurut Jim Ife dan Frank Tesoreiro (2006) seorang pendamping diharapkan mampu untuk mendirikan jalinan hubungan dengan beragam orang, dan mampu memanfaatkan hubungan tersebut dalam proses pengembangan masyarakat. Jaringan kerja merupakan hal utama yang perlu dikembangkan sehingga masyarakat dapat terhubung dengan sumbersumber yang dapat mereka manfaatkan bagi kebutuhan mereka.

Salah satu bentuk nyata pelaksanaan peran membangun jaringan kerja terlihat ketika pendamping membantu kelompok salah satu kelompok kerja yang mendapatkan bantuan KUBE untuk mengerjakan pekerjaan-pekerjaan pertukangan, mereka mempunyai kemampuan kerja yang baik dan orang yang menggunakan jasa mereka merasa puas atas hasil kerja mereka, tetapi mereka tidak mempunyai jaringan kerja dan mereka kesulitan untuk menemukan proyek baru untuk mereka kerjakan. Disini pendamping berperan membantu kelompok untuk membangun jaringan kerja baik dengan pihak pemerintah maupun dengan pihak swasta sehingga pihak-pihak tersebut dapat memanfaatkan kelompok kerja tersebut untuk mengerjakan proyek-proyek yang mereka miliki. Jika telah memiliki jaringan kerja maka penting bagi kelompok untuk menjaga kepercayaan dengan pihak-pihak tersebut.

Pentingnya jaringan kerja ini dapat mempermudah kelompok untuk mendapatkan produk-produk tertentu dalam menjalankan usaha mereka. Sehingga dikemudian hari dapat membantu masalah kelompok ketika mereka kesulitan untuk menemukan produk-produk tertentu untuk menjalankan usaha mereka.

3. Peran dalam membagi pengetahuan dan pengalaman

Peran pendamping yang sangat terlihat yaitu bagaimana seorang pendamping KUBE berbagi pengetahuan dan pengalaman yang ia miliki kepada kelompok. Berbagi pengetahuan dan pengalaman ini tidak hanya dilakukan satu arah dari pendamping kepada kelompok namun, pendamping juga dapat menerima pengetahuan-pengetahuan baru dari kelompok. Hal ini senada dengan apa yang disampaikan oleh Jim Ife dan Frank Tesoreiro (2006) bahwa penting bagi seorang pendamping untuk saling berbagi pengetahuan dan pengalaman yang dimilikinya dengan mereka yang didampingi hal ini dilakukan karena pendamping menyadari keterbatasan yang dimilikinya. Kegiatan ini perlu dikembangkan agar masing-masing pihak memiliki semangat, dan motivasi untuk saling belajar. 
Pendamping dan kelompok akan saling memberikan masukan, berupa pikiran-pikiran positif, berbagi pengetahuan dan belajar serta saling memotivasi, untuk pengembangan usaha. Dengan saling berbagi pengetahuan dan pengalaman didalam kelompok maka baik pendamping maupun anggota kelompok akan memiliki rasa tanggung jawab terhadap usaha yang sedang dijalankan sebab usaha tersebut dijalankan bukan atas pemikiran pribadi-pribadi tertentu tetapi atas pemikiran bersama.

D. Peran dan Keterampilan Teknis peran ini berkaitan dengan berbagai hal-hal teknis dalam pengembangan usaha kelompok. Dalam peran ini terdapat 2 peran spesifik pendamping yang dapat membantu KUBE dalam melakukan pengembangan usaha yaitu:

1. Peran dalam membantu kelompok menggunakan komputer

Menurut Jim Ife dan Frank Tesoreiro (2006) komputer mempunyai banyak potensi yang berguna bagi seorang pendamping seperti membuat skema pengembangan masyarakat, menjaga catatan finansial, menjaga sejumlah keterampilan dan sumber, menganalisis data, membuat surat, berita, poster dan selebaran. Komputer telah banyak memberikan akses atas berbagai kesempatan baru bagi proses komunikasi dan pengolahan informasi dalam pengembangan masyarakat.

Dalam menjalankan perannya pendamping KUBE biasanya menggunakan komputer untuk membantu pekerjaannya mengontrol perkembangan usaha kelompok, waktu pertemuan dengan kelompok serta berbagai laporan-laporan lain yang nantinya akan disampaikan kepada pihak Dinas Sosial Kota Ambon sebagai pihak yang memberikan bantuan.

Pendamping juga menggunakan komputer untuk menemukan informasiinformasi, yang berhubungan dengan pengembangan usaha kelompok. Selain pendamping yang menggunakan komputer, pendamping juga menyarankan agar kelompok yang telah mampu mengoperasikan komputer agar menginput cara kerja sampai kepada hasil dan juga perkembangan usaha yang telah kelompok lakukan ke dalam komputer, dengan maksud agar kelompok dapat dengan mudah melakukan kontrol terhadap perkembangan usaha mereka. Bagi kelompok yang belum mampu mengoperasikan komputer pendamping turut terlibat untuk melakukan pelatihan bagi mereka.

Penggunaan komputer juga akan memudahkan pendamping dan kelompok dalam bekerja, seperti mengontrol perkembangan usaha, pencatatan kehadiran anggota dalam bekerja, pencapaian tugas dari anggota, dan bahkan sampai pada pengelolaan keuangan.

2. Peran dalam melakukan presentasi verbal dan tertulis

Menurut Jim Ife dan Frank Tesoreiro (2006) dalam peran ini seorang pendamping akan melakukan banyak hal yang berkaitan dengan 
menulis antara lain: menulis laporan, mencatat saat rapat, dan kepentingan surat menyurat. Selain itu pendamping juga perlu memiliki kemampuan secara verbal seperti: mengekspresikan diri dengan baik, membuat presentasi lisan kepada kelompok atau masyarakat, menggunakan teknik audiovisual dengan baik dan lain sebagainya. Hal ini diperlukan untuk memfasilitasi dan meningkatkan pemberdayaan dalam masyarakat.

Presentasi verbal dan tertulis merupakan peran terakhir dari pendamping yang mampu membantu KUBE dalam pengembangan usaha. Peran pendamping disini akan membantu kelompok untuk mempresentasikan jenis-jenis usaha yang mereka miliki kepada berbagai pihak baik pemerintah maupun swasta. Menurut seorang pendamping KUBE sebuah presentasi usaha yang akan membuat pihak yang akan menggunakan jasa atau produk dari kelompok merasa yakin dengan apa yang telah mereka pilih. Dengan begitu kelompok usaha akan mempunyai konsumen tetap yang akan menggunakan jasa atau produk mereka, sehingga usaha yang mereka jalankan dapat terus berjalan dan bahkan akan berkembang.

\section{SIMPULAN}

Hasil dari penelitian ini menunjukan bahwa peran pendamping terhadap pengembangan usaha KUBE di Kota Ambon yang dianalisis dengan pendekatan Jim Ife dan Frank Tesoreiro
(2006) terdiri dari beberapa peran spesifik yang terdapat pada peran dan keterampilan fasilitatif, peran dan keterampilan mendidik, peran dan keterampilan representasi, serta peran dan keterampilan teknis.

Dari hasil penelitian ditemukan beberapa peran spesifik dari peran dan keterampilan fasilitatif yang cukup membantu KUBE dalam menjalankan dan mengembangkan usaha mereka antara lain peran dalam pemberian semangat sosial, peran dalam memfasilitasi kelompok,dan peran dalam melakukan komunikasi pribadi.

Dalam peran dan keterampilan mendidik, dari seluruh peran spesifik yang terdapat dalam peran dan keterampilan ini terdapat 2 peran spesifik yang dilakukan oleh pendamping untuk membantu kelompok dalam meningkatkan usaha mereka yaitu peran peningkatan kesadaran dan peran untuk memberikan informasi.

Dalam peran dan keterampilan representasi dalam kaitannya dengan pengembangan usaha KUBE peran yang dilakukan oleh pendamping meliputi beberapa peran spesifik yaitu peran dalam menggunakan media, peran dalam membangun jaringan kerja dan peran dalam membagi pengetahuan dan pengalaman.

Peran dan keterampilan pendamping yang terakhir adalah peran dan keterampilan teknis, dalam kaitannya dengan pengembangan usaha KUBE peran yang dilakukan oleh pendamping meliputi 2 peran spesifik 
yaitu peran dalam membantu kelompok menggunakan komputer, dan peran dalam melakukan presentasi verbal dan tertulis.

\section{DAFTAR PUSTAKA}

Badan Pusat Statistik Provinsi Maluku. (2018). Profil Kemiskinan Provinsi Maluku 2017. Ambon: BPS Provinsi Maluku.

Bahril, S.H. (2017). "Peningkatan Kesejahteraan Sosial Masyarakat Melalui Kelompok Usaha Bersama, Kecamatan Tombolo Pao, Kabupaten Gowa". Fakultas Dakwah Dan Komunikasi. Uin Alauddin Makassar

Banks, S., Butcher, H., Henderson, P., Robertson, J. (2003). Managing Community Practice: Principle, Policies and Programmes. Bristol: The Policy Press.

Departemen Sosial R I. (2008). Pedoman Pendamping Sosial. Jakarta: Departemen Sosial R I.

Ife, J. dan Tesoreiro, F. (2006). Alternatif Pengembangan Masyarakat di Era Globalisasi-Community

Development. Terj. Sastrawan Manullang, Nurul Yakin, M. Nursyahid. Yogyakarta: Pustaka Pelajar.

Moleong, J. L. (2006). Metodologi Penelitian Kualitatif. Bandung: PT Remaja Rosdakarya.

Putri, E.L., Dan Pambudi, A. (2014) Efektivitas Pelaksanaan Program Kelompok Usaha Bersama (Kube) Di Kelurahan Tegalpanggung, Kecamatan Danurejan, Kota Yogyakarta. ADINEGARA. Vol Mar (1).

Silalahi. (2009). Metode Penelitian Sosial. Bandung: Reflika Aditama.
Sitepu, A. (2016). Analisis Efektifitas Kelompok Usaha Bersama Sebagai Instrumen Program Penanganan Fakir Miskin. Sosio Informa. Vol. 2 (1) 53-68

Spradley dan Faisal. (1990). Formatformat Penelitian Sosial. Jakarta: PT Rajawali Press.

Subing, H.M.A. (2013).Faktor-Faktor Yang Mempengaruhi Keberhasilan Kelompok Usaha Bersama Serta Dampaknya Terhadap Pendapatan dan Pengentasan Kemiskinan di Provinsi Lampung. Jurnal Manajemen dan Bisnis. Vol. 3 (2) 160-177.

Suharto, E. (2009). Kemiskinan \& Perlindungan Sosial Di Indonesia. Bandung: Alfabeta CV.

Suradi dan Mujiadi. (2009). Pemberdayaan Masyarakat Miskin: Studi Evaluasi Penanggulangan Kemiskinan di Lima Provinsi. Jakarta: P3KS Press

Sutopo, A.S dan Arief, A. (2010). Terampil Mengolah Data Kualitatif Dengan NVIVO. Jakarta: Prenada Media Group.

United Nations Development Program. (2010). Human Development Report: 40-year Trends Analysis Shows Poor Countries Making Faster Development Gains. New York, USA: UNDP.

Yasin, H. (2015). Upaya Strategis Pemberdayaan Ekonomi Masyarakat Melalui Kelompok Usaha Bersama (Kube). Jurnal Administrasi Publik. Volume 5 (1). 38-42

Sumber Internet:

Kementerian Sosial Republik Indonesia. Kelompok Usaha Bersama. Diperoleh 
dari:https://www.kemsos.go.id/co ntent/kube

Sitepu, A., Roebjantho, H., Widodo, N., Amalia, A.D. (2016) Dampak Kelompok Usaha Bersama (KUBE) Dalam Penanggulangan Kemiskinan. Diperoleh dari: http://puslit.kemsos.go.id/berita/ 378/keberlangsungan-programkube-perlu-pendampinganintensif\#sthash.pYI3RX1D.dpbs 